\title{
Efficacy of systemic HS-198, an analogue of oxymorphone, on cancer pain-related behaviour in mice
}

\author{
Muhammad F Asim ${ }^{1}$, Catalina R Bohotin ${ }^{1}$, Cristina E Constantin² ${ }^{2}$. Helmut Schmidhammer ${ }^{1}$, Michaela Kress ${ }^{2}$, \\ Mariana Spetea ${ }^{1 *}$
}

From 17th Scientific Symposium of the Austrian Pharmacological Society (APHAR). Joint meeting with the Hungarian Society of Experimental and Clinical Pharmacology (MFT)

Innsbruck, Austria. 29-30 September 2011

\section{Background}

Cancer pain is a significant clinical problem being one of the first symptoms of disease with $75-90 \%$ of the patients experiencing chronic pain syndromes in advanced stages [1]. The management of cancer pain is mainly based on the use of opioid drugs; however their clinical use is limited by high incidence of adverse effects. There is a continued search for highly efficacious opioid analgesics with reduced complications and improved patient compliance. An analogue of the clinically used oxymorphone, 5-methyl-substituted 14-O-methyloxymorphone (HS198 ), is a selective $\mu$ opioid agonist and a potent antinociceptive agent in animal models of nociceptive and inflammatory pain, while exhibiting a favourable dissociation between analgesia and the occurrence of side effects [2]. We report data on efficacy of this opioid agonist after subcutaneous administration (s.c.) in a murine model of cancer pain. The opioid receptor-mechanistic basis of the antinociceptive action was also investigated.

\section{Methods}

Cancer pain was induced in C57BL/6J mice by s.c. implantation of lung carcinoma cells, in the plantar and dorsal side of the right hindpaw [3]. Mechanical sensitivity was determined using von Frey monofilaments. Heat sensitivity was assessed using the Hargreaves test. In vitro biological activities were evaluated using binding and functional assays.

\footnotetext{
* Correspondence: mariana.spetea@uibk.ac.at

'Department of Pharmaceutical Chemistry, Institute of Pharmacy and Center for Molecular Biosciences, University of Innsbruck, 6020 Innsbruck, Austria Full list of author information is available at the end of the article
}

\section{Results}

On day 9 post-inoculation, s.c. HS-198 produced a dosedependent inhibition with significant effects in attenuating cancer pain-related behaviour (thermal and mechanical hypersensitivity) on the tumour side. Pre-treatment with the opioid receptor antagonist naloxone reversed the antinociceptive effects induced by HS-198 in mice with cancer-induced pain. In vitro, HS-198 showed high affinity and selectivity for both mouse and rat $\mu$ opioid receptors, and it displayed potent $\mu$-agonism through inhibition of $\mathrm{G}$ proteins.

\section{Conclusions}

Systemic s.c. administration of the $\mu$ opioid receptor agonist HS-198 induces potent antinociceptive effects in mice with cancer pain via opioid receptor-specific mechanisms.

\section{Acknowledgements \\ Supported by the Austrian Science Fund (FWF: TRP 19-B18).}

\footnotetext{
Author details

'Department of Pharmaceutical Chemistry, Institute of Pharmacy and Center for Molecular Biosciences, University of Innsbruck, 6020 Innsbruck, Austria. 2Division of Physiology, Department of Physiology and Medical Physics, Innsbruck Medical University, 6020 Innsbruck, Austria.

Published: 5 September 2011
References
1. Mantyh PW: Cancer pain and its impact on diagnosis, survival and quality of life. Nat Rev Biosci 2006, 7:797-809.
2. Schmidhammer H, Spetea M: Synthesis of 14-alkoxymorphinan derivatives and their pharmacological actions. Top Curr Chem 2011, 299:63-91.


3. Constantin CE, Mair N, Sailer CA, Andratsch M, Xu ZZ, Blumer MJ, Scherbakov N, Davis JB, Bluethmann H, Ji RR, Kress M: Endogenous tumor necrosis factor a (TNFa) requires TNF receptor type 2 to generate heat hyperalgesia in a mouse cancer model. J Neurosci 2008, 28:5072-5081.

doi:10.1186/1471-2210-11-S2-A4

Cite this article as: Asim et al:: Efficacy of systemic HS-198, an analogue of oxymorphone, on cancer pain-related behaviour in mice. BMC

Pharmacology 2011 11(Suppl 2):A4.

Submit your next manuscript to BioMed Central and take full advantage of:

- Convenient online submission

- Thorough peer review

- No space constraints or color figure charges

- Immediate publication on acceptance

- Inclusion in PubMed, CAS, Scopus and Google Scholar

- Research which is freely available for redistribution

Submit your manuscript at www.biomedcentral.com/submit
Ciomed Central 